\title{
Case Report: SECONDARY LAPAROSCOPIC ASSISSTED TRANSANAL ENDORECTAL PULL-THROUGH. A PRE-ELIMINARY STUDY
}

\author{
Barmadisatrio, Hariono \\ Pediatric Surgery Division, Department of Surgery \\ Faculty of Medicine, Universitas Airlangga \\ Dr Soetomo Hospital, Surabaya
}

\begin{abstract}
ABSTRAK
Dengan berkembangnya operasi minimal invasif, mulai banyak sentra bedah di dunia menggunakan LATEP sebagai teknik operasi pada penyakit Hirschsprung. Keuntungan operasi minimal invasif pada penyakit Hirschsprung dibanding operasi open antara lain mempercepat waktu pemberian intake per oral, mempercepat pemulangan penderita, dan memperingan nyeri. LATEP sekunder merupakan salah satu operasi definitif pull-through pada penyakit Hirschsprung yang sebelumnya telah menjalani operasi pembuatan stoma. Keterbatasan fasilitas kesehatan, belum meratanya tenaga spesialis bedah anak di Indonesia dan keterlambatan diagnosis menyebabkan sebagian besar penderita penyakit Hirschsprung tidak dapat dilakukan tindakan definitif pull-through primer. Di RSUD dr. Soetomo Surabaya telah dilakukan 6 operasi LATEP sekunder selama bulan Januari hingga Agustus 2014. Dari 6 kasus tersebut operasi dilakukan pada anak usia termuda 6 bulan dan tertua 8 tahun, yang sebagian besar telah dibuat stoma pada usia 4 hari. Dari 5 kasus tersebut semua anak masih hidup, dengan 1 anak masih dengan stoma post operasi karena ditemukan enterocolitis dan mengalami komplikasi stenosis pada anastomose 2 minggu post operasi, 3 anak mengalami komplikasi enterocolitis post operasi, 1 anak sembuh, dan 1 anak masih dalam perawatan post operatif. Sebagai simpulan, LATEP sekunder merupakan alternatif operasi untuk penderita penyakit Hirschsprung yang sesuai dengan kondisi sosial-ekonomi di Indonesia, namun untuk pelaksanaannya secara menyeluruh masih harus dipelajari serta dikembangkan lebih lanjut. (FMI 2016;52:74-79)
\end{abstract}

Kata kunci: LATEP sekunder, penyakit Hirschsprung, operasi minimal invasive

\begin{abstract}
The definitive treatment for Hirschsprung's disease is pullthrough procedure, that can be done through conventional pullthrough approach or through minimal invasive approach. The benefit of minimal invasive technique compared to conventinal open procedure is shorter time to oral intake, shorter length of stay, and less postoperative pain. Secondary LATEP is a minimal invasive pull through technique in patients with preexisting colostomy. Primary pullthrough sometimes cannot be done because limitation of health facilities, uneven distribution of pediatric surgeons throughout the country and late diagnosis of Hirschsprung's Disease. In dr Soetomo Hospital Surabaya, 7 secondary LATEP procedures were done in January to August 2014. The age range was 6 months to 8 years old. All patients survived, 1 patient had stenosis of anastomotic site 2 weeks postoperative, 3 had enterocolitis, 3 with no complication. Secondary LATEP is a minimal invasive approach for Hirschsprung's Disease that can be adjusted with Indonesia's social and economic condition, where most population was distant from an adequate health facility. As there is high incidence of malnutrition, enterocolitis and also the distance from appropriate health services, stoma formation is the first thing that can be done before definitive treatment.Secondary LATEP has never been done in Indonesia, and we still need more data and research to evaluate the benefit and disadvantage of this approach compared to conventional or minimal invasive primary pull through. In conclusion, secondary LATEP is an appropriate pullthrough alternative for Hirschsprung's Disease and applicable in Indonesia, considering the social and economy condition. Further study must be done to develop this method. (FMI 2016;52:74-79)
\end{abstract}

Keywords: LATEP secondary, Hirschsprung's disease, minimally invasive surgery

Correspondence: Barmadisatrio, Pediatric Surgery Division, Department of Surgery, Faculty of Medicine, Universitas Airlangga, Dr Soetomo Hospital, Jl. Prof dr Moestopo 6-8, Surabaya 60286, Indonesia. Email: dodolily1997@gmail.com

\section{INTRODUCTION}

Hirschsprung disease, also called congenital megacolon disease is a congenital abnormality in which aganglion segment is present in the intestine, so that the area cannot develop and defecation becomes disturbed.
Classic triad of clinical features in patients with Hirschsprung's disease is delayed meconiu, ie more than the first 24 hours, green vomiting, and abdominal bloating. The presence of chronic obstipation is also often accompanied by enterocolitis complication due to excessive growth of bacteria in the colon ischemia due to 
distension (Sjamsuhidajat $\mathrm{R}$ and De Jong W 2005). Treatment for Hirschsprung's disease is surgery. Surgery for Hirs-chsprung's disease was first introduced by Swenson, then came the new technique with submucosal dissect-tion introduced by Soave, and retrorectal techniques was then introduced by Duhamel. With the development of science and technology, minimally invasive technique has been introduced, which is using pullthrough with laparoscopic surgery technique (Langer 2012). All surgical techniques have its advantages and disadvant-ages, depending on the initial conditions of the patient and the ability of the surgeon to perform the action.

Minimally invasive surgery with laparoscopic technique itself is believed to provide postoperative benefits for the patients compared to open surgery. It is accelerating the timing of oral intake, speed up the discharge of the patient, and alleviating pain (Langer 2012). In Hirschsprung's disease, primary laparoscopic pullthrough techniques was introduced by Georgeson in 1995, to identify a transitional zone, intraoperative biopsy, and mobilize proximal portion of the rectum and sigmoid using laparoscopy. This procedure is followed by endorectal transanal pullthrough (Granstrom et al 2013).

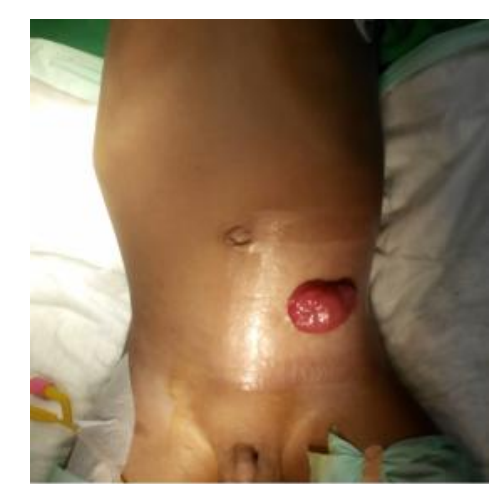

Fig. 1. Stoma has been made prior to definitive surgery

Hirschsprung disease patients with complications may come with the condition of malnutrition and enterocolitis. In such condition, stoma colostomy should be made as the first action followed with pull-through procedure several months later (Sjamsuhidajat $\mathrm{R}$ and De Jong W 2005, Langer 2012). In such condition the laparoscopic approach can be done with the hope to get outcome similar or better than the open pullthrough technique.
Secondary laparoscopic assisted trans-anal endorectal pullthrough (LATEP) is one of the pull-through in definitive surgery in Hirschsprung's disease who had undergone stoma surgery. This definition is actually not standard, because it has not been done in Indonesia and abroad. Secondary LATEP is applied by adjusting the socio-economic conditions in Indonesia, where there are limited health facilities, uneven distribution of pediatric surgical specialists in Indonesia, and delayed diagnosis that causes most patients with Hirschsprung's disease cannot be subjected to primary pull-through definitive procedure.

\section{CASE REPORT}

From January to August 2014 we had conducted six secondary LATEP operations in Dr. Soetomo Hospital Surabaya. In such cases all patients were male; secondary LATEP operation was performed on children, the youngest was 6 months old and the oldest 8 years, with mean age of 3.5 years. All patients had earlier stoma surgery, in which the youngest was 4 days old and the oldest was 7 years; with an mean age of 2 years. All patients presented with delayed first bowel movement, which was over 24 hours, irregular bowel movements (averagely 1-3 times a week), and averagely needed laxatives to defecate. In addition, majority of patients had a history of enterocolitis, with signs of big mushy liquid, odorous and pungent stool, with or without systemic symptoms, such as fever.

All patients underwent definitive surgery with secondary LATEP, which performed laparoscopically to identify transitional zone in rectosigmoid area, which had previously been estimated through lopography through distal stoma. After the transitional zone was identified, a biopsy was performed on the area to determine ganglion area boundary, and followed by mobilizing the sigmoid colon and rectum. Then, the last step was the closure of stoma and Transanal pullthrough. Of 6 patients, 1 patient performed laparoscopic assissted pullthrough while maintaining a stoma created previously. This was done because during exploratory surgery it was found that distal segment was considered quite normal, so the removal of the entire distal segment to the stoma was not needed. With laparoscopic guidance, identification found surprisingly short segments aganglion, so it was simply handled with transanal pullthrough with assissted laparoscopy on the short aganglion segment. Thereafter, the closure of stoma was done approximately 6 months after pullthrough procedure. 
Table 1. Data of patients who performed secondary LATEP surgery in Dr. Soetomo Hospital, Surabaya, January - August 2014

\begin{tabular}{|c|c|c|c|c|c|c|}
\hline No & Age & Sex & $\mathrm{AP}$ & Course & $\begin{array}{c}\text { Early } \\
\text { Complicatoins }\end{array}$ & $\begin{array}{c}\text { Advanced } \\
\text { Complications }\end{array}$ \\
\hline 1 & 6 months & Male & $\begin{array}{c}\text { Proximal } \\
\text { ganglion } \\
\text { sufficient }\end{array}$ & 7 days & $\begin{array}{l}\text { Fever (-) } \\
\text { Diarrhea(+) } \\
\text { Flatulence (-) } \\
\text { Vomiting (-) } \\
\text { SSI (-) }\end{array}$ & $\begin{array}{l}\text { Enterocolitis (+) } \\
\text { Stenosis (-) }\end{array}$ \\
\hline 2 & 15 months & Male & $\begin{array}{l}\text { Proximal } \\
\text { ganglion } \\
\text { sufficient }\end{array}$ & 13 days & $\begin{array}{l}\text { Fever (-) } \\
\text { Diarrhea (+) } \\
\text { Flatulence (-) } \\
\text { Vomiting (-) } \\
\text { SSI (-) }\end{array}$ & $\begin{array}{l}\text { Enterocolitis }(+) \\
\text { Stenosis }(+)\end{array}$ \\
\hline 3 & 18 months & Male & $\begin{array}{l}\text { Proximal } \\
\text { ganglion } \\
\text { sufficient }\end{array}$ & 12 days & $\begin{array}{l}\text { Fever (-) } \\
\text { Diarrhea (-) } \\
\text { Flatulence (-) } \\
\text { Vomiting (-) } \\
\text { SSI (-) }\end{array}$ & $\begin{array}{l}\text { Enterocolitis (-) } \\
\text { Stenosis (-) }\end{array}$ \\
\hline 4 & 5 years & Male & $\begin{array}{c}\text { Proximal } \\
\text { ganglion } \\
\text { sufficient }\end{array}$ & 14 days & $\begin{array}{l}\text { Fever (-) } \\
\text { Diarrhea }(+) \\
\text { Flatulence }(+) \\
\text { Vomiting }(-) \\
\text { SSI (-) }\end{array}$ & $\begin{array}{l}\text { Enterocolitis }(+) \\
\text { Stenosis }(-)\end{array}$ \\
\hline 5 & 5 years & Male & $\begin{array}{c}\text { Proximal } \\
\text { ganglion } \\
\text { sufficient }\end{array}$ & 13 days & $\begin{array}{l}\text { Fever (-) } \\
\text { Diarrhea (-) } \\
\text { Flatulence (+) } \\
\text { Vomiting (-) } \\
\text { SSI (-) }\end{array}$ & $\begin{array}{l}\text { Enterocolitis (-) } \\
\text { Stenosis (-) }\end{array}$ \\
\hline 6 & 8 years & Male & $\begin{array}{l}\text { Proximal } \\
\text { ganglion } \\
\text { sufficient }\end{array}$ & 12 days & $\begin{array}{l}\text { Fever (-) } \\
\text { Diarrhea (-) } \\
\text { Flatulence (-) } \\
\text { Vomiting (-) } \\
\text { SSI (-) }\end{array}$ & $\begin{array}{l}\text { Enterocolitis (-) } \\
\text { Stenosis (-) }\end{array}$ \\
\hline
\end{tabular}
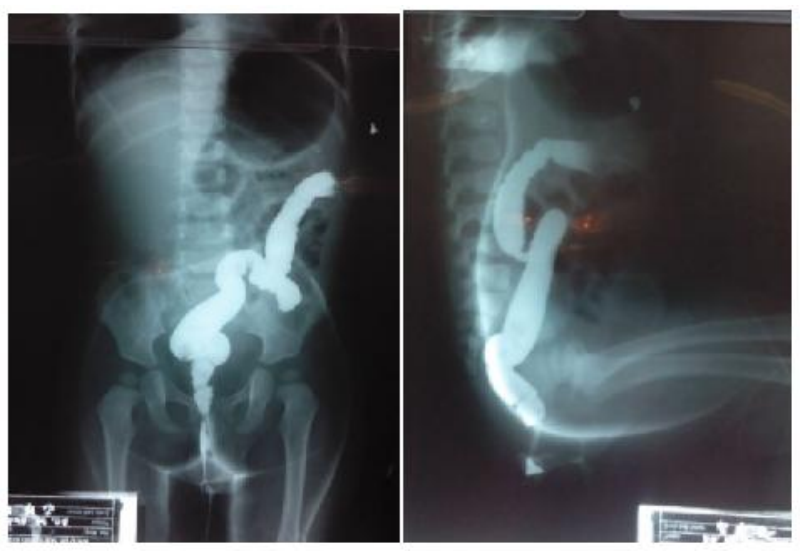

Fig. 2. Overview of transitional zone in patients with examination lopography

All patients were fasted from solid food only for one day and start eating soft foods since the second day. On average, the patients were hospitalized for 12 days, and discharged after day 4 to 4 day 6 postoperative treatment. All patients had no complaints on postoperative wound and no complications of infection in the surgical wound.
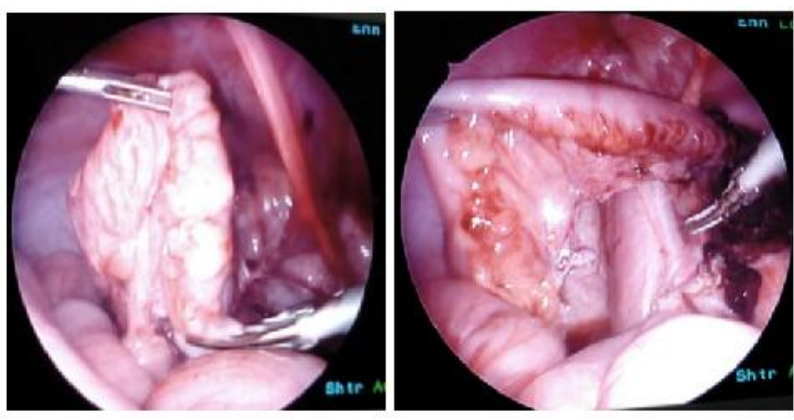

Fig. 3. Transitional zone identification and mobilization via laparoscopy

Of the six children who had secondary LATEP surgery, during post-operative treatment at the hospital, three had complications such as diarrhea with mushy consistency to liquid and pungent. One child suffered from bloating within 2-3 days post-surgery, but there were no signs of gastrointestinal infections. 

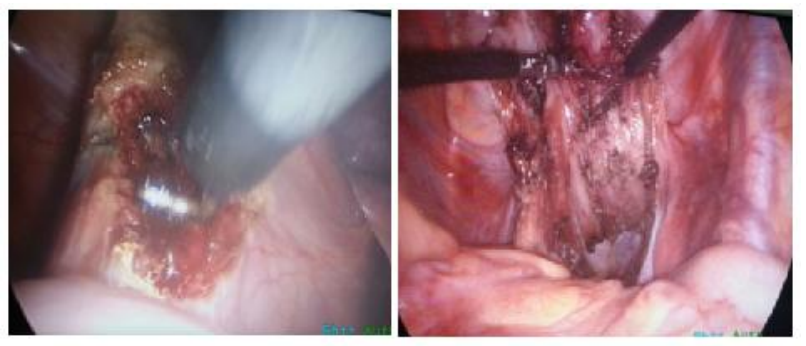

Fig. 4. Freeing retrorectal space through laparoscopy

Clinically, there were no signs of systemic infection in all children after the operation, and all children could receive oral intake in post-operative care in the hospital. After their condition was better, they were discharged and observation was done in the clinic in 3-7 days after hospital discharge.

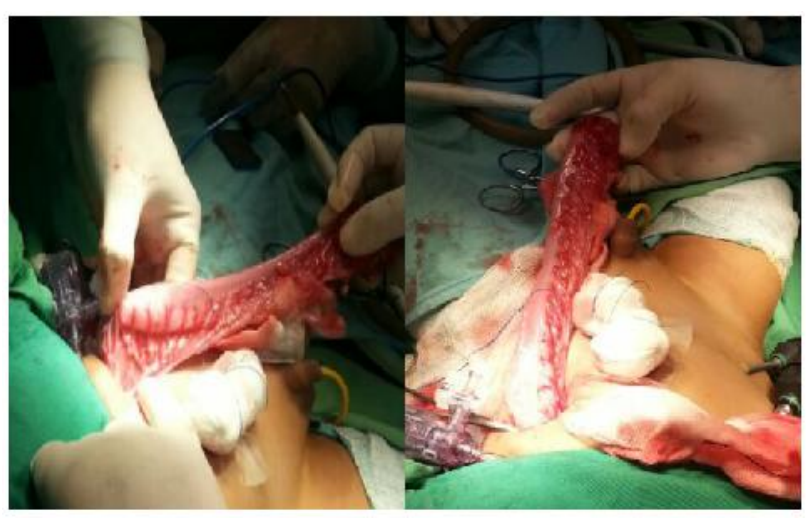

Fig. 5. Freeing stoma for pullthrough preparation

During the observation in the clinic, two children had no complaints from day 10 post-surgery, three children experienced postoperative complications of enterocolitis, and one child had stenosis complications in anastomosis within 2 weeks post surgery.
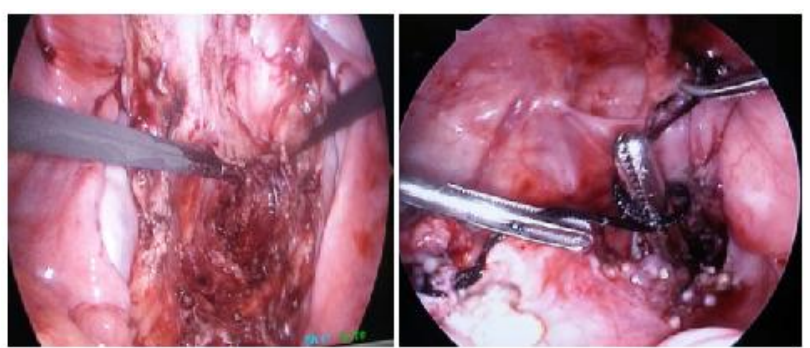

Fig. 6. Pullthrough preparation with clamps from prepared retrorectal space
Of the three children who suffered from postoperative enterocolitis, all experienced symptoms of liquid stool, sometimes accompanied by mucus, irritation of the skin around the anus, and difficult to hold the bowel movement. However, during in the next observation, all children had improved condition, with less frequent symptom of defecation, do not stink, even one child had recovered and had no complaints since day 20 postsurgery.

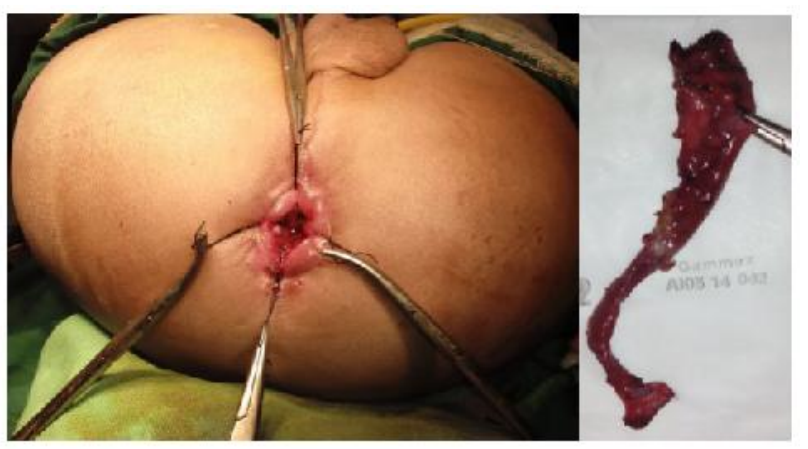

Fig. 7. The surgery was proceeded with pullthrough and stoma closure

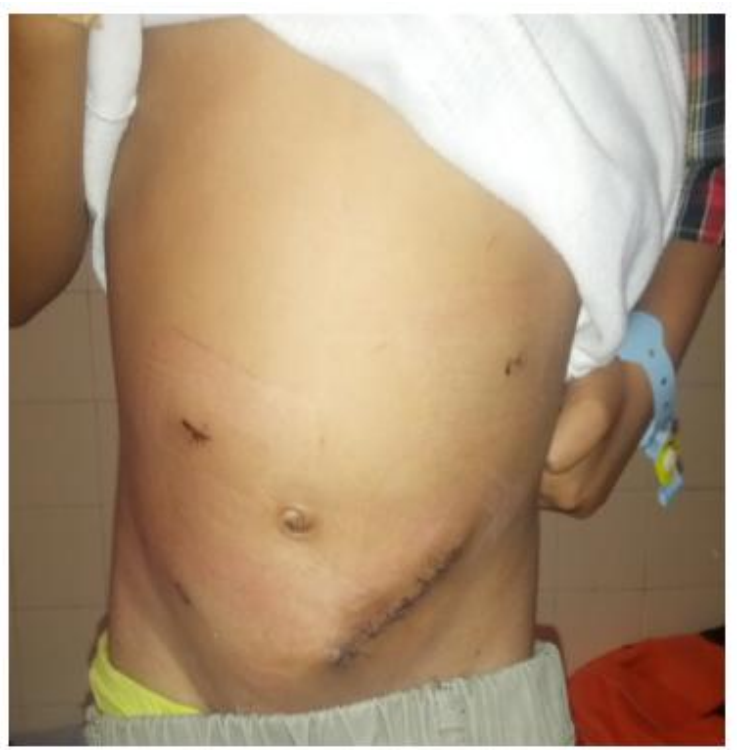

Fig. 8. Post secondary LATEP surgery

After follow-up in 6 months postoperatively, three children were found to recover without complaint, two children who previously suffered enterocolitis, started to improve since the second month post-surgery, but still had recurrent diarrhea with much less frequency than before, and one child had stenosis at anastomosis. Stoma colostomy closure was done in the fve months 
post LATEP, after periodic dilatation has been done and regarded as reliable.

\section{DISCUSSION}

Secondary LATEP is a technique of minimally invasive surgery for Hirschsprung's disease which is adapted to the socio-economic conditions in Indonesia, where good health facilities are less affordable for many residents. It is one of the factors causing delays in treatment in children with Hirschsprung's disease. In addition, the level of public education is still low and the lack of awareness in Indonesia on health are other factors causing difficulties and complications in the treatment of Hirschsprung's disease.

With the high incidence of malnutrition and enterocolitis in children with Hirschsprung's disease and the difficulty of achieving adequate health facilities, stoma is the first treatment that can be performed before definitive surgery. Stoma is also the best choice in children with Hirschsprung's disease with large dilatation of proximal colon of the transition zone, total aganglionic colon, or inadequate support for the pathological condition of the patient.

Although secondary LATEP is a minimally invasive technique, the risk of postoperative complications may still occur. Postoperative complications can be divided into complications that can be prevented in advance (leakage, infection, aganglionic segment remains), complications can be prevented in part (constipation, dermatitis), and complications that cannot be prevented (enterocolitis) (Leape 1987, Van de Ven et al 2013). From a study conducted by Langer, long-term problems that may occur after pullthrough surgery are, among other, symptoms of obstruction, soiling, and enterocolitis. Symptoms of obstruction occurs in approximately $30 \%$ of post pullthrough patients which include abdominal distention, bloating, borborygmi, vomiting or severe constipation. Causes of persistent obstruction symptoms include mechanical obstruction, recurrent or acquired aganglionosis, impaired motility in proximal colon or small intestine, disruption of internal anal sphincter relaxation, or delayed bowel habits. However, almost all patients with Hirschsprung's disease, despite having risks for complications in the first years postoperative, finally have a very good quality of life when they grow up (Langer 2012).

In the case of Hirschsprung disease with secondary LATEP operations in dr. Soetomo Hospital, stoma had been made to all patients before and they had history of enterocolitis signs. In one child, stoma was not closed done during surgery as he indicated enterocolitis symptoms during surgery, and in postoperatively they experienced stenosis complications in anastomose area. There were two patients who had no complaints since the 10th day postoperatively, but half of the patients experienced postoperative enterocolitis complications, and improved after treatment with routine wash-out and medications (antibiotics). In 6 months post-surgery follow-up, there were two patients who had bowel complaints with repetitive liquid consistency, but not accompanied by systemic disorders. In patients with stenosis of anastomose, dilatation was done periodically and had stoma closure done in 5th month post LATEP, with no sign of postoperative obstruction.

However, with relatively small number of the patients who had secondary LATEP, it was not enough to conclude that the secondary LATEP operation has advantages over other techniques in dealing with Hirschsprung's disease. Secondary LATEP itself has not been generally done and there was no comparative advantage over primary and operation LATEP open. In this preliminary study we found a pretty good outcome, which from 6 patients who underwent secondary LATEP surgery, 4 have been cured and no complaints. However, there were still patients who experienced post-operative complications of enterocolitis. Therefore, further study is still needed on secondary LATEP, which is expected to become an alternative operation on Hirschsprung's disease in accordance with the socioeconomic culture in Indonesia, and if possible in order to compare with other operations, particularly to open surgery techniques.

\section{CONCLUSION}

Secondary LATEP is an alternative surgery for Hirschsprung's disease in accordance with the socioeconomic conditions in Indonesia. Secondary LATEP is expected to give advantages of minimally invasive surgery and reduce postoperative complications of stoma as treatment for Hirschsprung's disease.

\section{REFERENCES}

Sjamsuhidajat R and De Jong W (2005). Buku Ajar Ilmu Bedah, Jakarta, EGC

Langer JC (2012). Laparoscopic and transanal pullthrough for hirschsprung disease. Seminars in Pediatric Surgery 21, 283-290

Granstrom AL, Husberg B, Nordenskjöld A, Svensson P, Wester T (2013). Laparoscopic-assisted pullthrough for Hirschsprung's disease, a prospective repeated evaluation of functional outcome. Journal of Pediatric Surgery 48, 2536-2539 
Leape LL (1987). Patient Care in Pediatric Surgery (Little, Brown patient care series), Boston, Little Brown \& Co

van de Ven TJ, Sloots CE, Wijnen MH, Rassouli R, van Rooji I, Wijnen RM, de Blaauw I (2013). Transanal endorectal pull-through for classic segment Hirschsprung's disease: With or without laparoscopic mobilization of the rectosigmoid?. Journal of Pediatric Surgery 48, 1914-1918 